\title{
Ventura Capital Company As An Alternative Financing Source For Smies Development In Solok City
}

\author{
D.Sartika ${ }^{1}$, Firwan $\operatorname{Tan}^{2}$, Endrizal. ${ }^{3}$ \\ \{sartika_1985@yahoo.co.id,drfirwan@yahoo.com, adyulius@yahoo.co.id\} \\ ${ }^{1}$ Faculty Of Economics and Business Bina Darma University, Ahmad Yani Street No.3, Palembang- \\ Indonesia \\ ${ }^{2,3}$ Faculty Of Economics Andalas University, Campus Limau Manis, Padang-Indonesia
}

\begin{abstract}
The aims of this research are to analyze and to discuss two things: (i)the effects of venture capital investment to the development growth of Small and Medium Industrial Enterprise (SMIEs); (ii)the capital needed to start-up of SMEIs; (iii)the market prospective of venture capital company (VCC) in Solok City. Research method used is descriptive and quantitative statistical analysis. The research findings show that (i)using "OLS equation model" has proved the important of VCC's creation and development in Solok City, it is indicated by the value of parameter coefficients of OLS equation model which influence significantly the dependent variable; (ii)the expected capital need of start-up SMES in the year of 2015 according to 84 respondents is $\mathrm{Rp} 6.150 .000 .000$., but the credit provided from bank is only Rp 3.020.000.000., meaning from the bank side not all of credit demanded available. This implies the market opportunity is opened to non bank institution such as VCC. Furthermore, HDI Kota Solok is 77, 44 (2017), it is categorized as a quite high value due to far greater than 50.00. High value of HDI gives a stronger support to SMIEs development and often used by VCC as a main indicator to determine the business partner company (BPC) to be financed. In short, the research findings confirmed that VCC is needed and its market opens widely to stimulate the growth of SMIEs and economy of Solok City now and in the future.
\end{abstract}

Keywords: Small and Medium Industrial Enterprise (SMIEs), Business Partner Company (BPC) of VCC, and Human Development Index (HDI)

\section{Introduction}

The vision of the long-term development plan of the Solok City is to "make the Solok City as a city of trade, service and education centers in the Central Sumatra Region of 2025". This research, focused on related studies by making the City of Solok as a trading city and related supporting services for trade activities. The research in 2012 conducted by F.Tan (tanabout the action plan of trade and services development in Solok City (2014-2016) indicated that there are two program actions should be raised, i.e: institutional and structural innovation policies. The priority program in term of institutional innovation policy is creation and development of VCC in Solok City which is called as Solok Venture Capital (SVC). This is for the purposes to support the acceleration of SMIEs growth and development in Solok City. Hopely, the SVC development model can be as a good example in order to create and 
develop VCCs at other district and municipality level in Indonesia [1]. SMIEs are identical in Indonesian Language as Industri Kecil dan Menengah, abbreviated IKM. SMIEs are considered as an important business actor in Solok City. This field dominates the economic activities, particularly in term of industrial and trade activities in Solok City. The number of SMIEs in the year of 2014 is 2.037. Among them 24, 25 percent (494) is the actors of SMIEs and 75, 75 percent (1.543) are SMEs (BPS 2014, data processed). The activities of SMIEs in Solok City among other include cracker industry, bread industry, Tempe/tohu industry, woven industry, printing industry, textile goods industry and others. Therefore the attention to this sector is quite high given by the Solok City Government.

The research study Venture Capital is, Entrepreneurial orientation does significantly positively affect new venture performance, but the indirect impact of new venture capability is stronger [2]. the entry and prevalence of commercial ventures in a region negatively influence the creation of social ventures, commercial ventures' exits have a positive influence [3]. The entrepreneur's strong social ties with the scientific community and technology-orientated cognition drive research collaborations and ultimately contribute to new venture innovation [4]. Structural autonomy of a CVC program is significantly related to its investment portfolio diversification [5]. entrepreneurial experience, manpower and creativity have positive impact on new venture's performance assessed by using profitability and patents creation as the criterion variables. Amongst all predictors, entrepreneurial manpower was found to have the strongest effect on both profitability and patent creation. The most interesting finding, however, stemmed from a component of entrepreneurial motivation the authors created, pioneering motivation. This unique form of motivation, to explain the extreme determination and time involved in starting a new business, was found to have a significantly negative effect on patent creation.[6]. India and China were consistent net importers of VC deals, with China emerging as the largest net importer of $\mathrm{VC}$.[7]. The results of this study also found that knowledge diversity of the investing firm moderates the inverted U-shaped relationship.[8].

The difficulty to get the capital sources for SMIEs in Indonesia is still as a classical problem since a long time. Its problem is due to no matching between the conditions demanded by bank side with the capability of SMIEs to provide it. The interest rate imposed by bank is still relatively high, the procedure imposed is still complicated, the credit guarantee requested is still too expensive, and still many other condition requirements are difficult to fulfill by SMIEs. These reasons why most of SMIEs do not want to borrow many from the banks. The limitation of capability SMIEs to fulfill bank requirement create a great opportunity to access the capital sources from non-bank institutions such VCC. The problem is this kind of non-bank institutions, are not many in Indonesia, if there is, and it is available only at the provincial level and at the big group companies. It can be said that VCC is not yet existed at mostly of district and municipality. VCC is not yet established in Solok City at least until the research is conducted. The limitation of bank capability to serve SMIEs create the big opportunity of establish and developing VCC in the districts and municipalities in Indonesia. According to several studies showed that most of VCC now day in Indonesia tend to practice its role as like as the bank. It is very contradictory with the theory of venture capital as what it should be. In West Sumatra for example, VCC called Sarana Sumatera Barat Ventura with abbreviation SSBV, has been established since 1995. Nevertheless, in the last ten years SSBV play its roles as like as the bank. The government intervention in this case is necessary in order to put VCC is on the right tract.

From point of view theoretical aspects, as a venture capital company is a financial institution non-bank. Therefore VCC does not supply a credit as what done by a bank. The VCC is an investment institution, it provides the amount of investment in form of equity or 
share financing to BPC in limiting time period, normally for six years in maximum. This is the reason why a SMIEs as a receiver of investment funds from VCC is not called as a client but it is called as BPC. In Indonesian Language BPC is called by "Perusahaan Pasangan Usaha (PPU)", between PPU or BPC with VCC are working together to develop a joint venture company. It means that the responsibility of risk of business must be taken altogether of both VCC and BPC. For objective to eliminate the risk, thus VCC is necessary to intervene in BPC management as a companion and participate in directing BPC's strategic business. The advantages of BPC taken by joining with VCC are financing supports, management accompaniment, and support in developing marketing networks. Moreover, VCC prefers to invest in industrial activities, it implies that VCC tend to choose the field of activities in term of manufacturing because of this business activities which can increase the greater added values in comparison to the others field of businesses.

Economic growth of the regions is very dependent on the quality of labor and the amount of capital stock [2]. Therefore investment in the form of venture capital becomes increasingly important to encourage the acceleration of industrialization to reach the countryside. From an economic point of view, investment as a factor to push production, investment can be confined in various forms, for example buying shares, bonds, or other investments; an act of buying capital goods; and utilization of available funds for production with future income [4]. Investment is an important factor in the process of economic growth. The VCC investment will encourage an increase in capital per workforce (per capita) so as to increase income per capita and regional. the main cause of the weak development progress of 8 . the main cause of the weak development progress of 8 determinants of the acceleration of economic progress of the entrepreneurial business in the region is due to the unavailability of institutions that serve as "Support Services" for the development of the 8 main factors determining the success of the entrepreneurial economy business in the region[9].

From the description above, thus this research will examine more deeply about the following matters: (i) how the influence of venture capital investment on the development of SMIEs; (ii) how much the capital needs of a SMIEs; (iii) how is the prospective market of VCC to encourage the development of SMIEs in the regions of Solok City. Thus, this research is in the framework of conducting a study in the efforts to establish a VCC in Solok City. And hope the results of this study will be used as a reference for development in other places.

\section{Methodology}

There are three essential kinds of questions which have to be answered in this research: the first is how important of VCC necessary to establish in Solok City; the second is how much the start-up capital needed by SMIEs; and the third is how big the market opportunity of VCC in Solok City?. For this purpose, the data used are primary and secondary data. While the primary data collection techniques are interviews with chief of related government offices such as Regional Development Planning Board (BAPPEDA), Solok City Industry and Trade Cooperative Office, the mayor staff of economic section of Solok City, and the actors of SMIEs in Solok City. While the secondary data used is in form of "time series data". These data are analyzed for the period of ten-years (2005-2014), the data taken from related institutions such as from Indonesian Central Bank which concerns with the data of credit supply and VCC of West Sumatra Province (SSBV) is the source of the data concerning of 
venture capital investment to BPC. Other supporting secondary data is sourced from the West Sumatra Statistics Agency.

The population of this study was the actors of SMIES in Solok City, which numbered 494 SMIEs players. Not all of population going to be studied, only several sample are going to be analized. Therefore, simple random sampling is the technique uses, the number of samples selected based on the results of the calculation of the Taro Yamane formula, i.e:

$$
n=\frac{N}{N \cdot d^{2}+1} n=\frac{494}{494 \cdot 0,1^{2}+1}
$$

$\mathrm{n}=83,16 \sim 83$ as respondents, those are the actors of SMIEs in Solok City.

There are several ways of analysis methods used, i.e.:

1. For the purpose to well understanding about the functional relationship within the period of ten years between the number of BPC with the fluctuation of independent variables, i.e.: the amount of credit from bank in term of rupiah (2005-2014) and the investment from SSBV to BPC in term of rupiah (2005-2014). Thus the VCC of West Sumatra Province or SSBV is nominated as "the object of case study". By using a simple regression equation model, i.e.: Ordinary Least Square (OLS) (Sofyardi, 2011). Therefore, a functional relationship can be written as follows:

Where:

$$
\begin{aligned}
& Y=f(X 1, X 2,) \\
& Y=\beta o+\beta 1 X 1+\beta 2 X 2+\varepsilon
\end{aligned}
$$

$\mathrm{Y} \quad=$ the number of BPC in the Province of West Sumatra, as a dependent variable;

$\mathrm{X} 1=$ the amount of investment of VCC (SSBV) to BPC in the Province of West Sumatra

X2 $=$ the amount of credit from bank to debtors in the Province of West Sumatra

$\beta 0=$ intercept

$\beta 1, \beta 2,=$ the value of coefficients parameter of independent variables

2. For purpose to determine the capital needs of start-up SMIEs, the frequency analysis method is going to be used. In this context the data from the field survey such as direct interview with stakeholders and questioners are used.

3. For purpose to understand the future market of VCC in Solok City, thus the analysis is based on the data taken from desk study and questioners.

\section{Results and Discussion}

\subsection{Analysis and discussion the results of "OLS equation"}

Table 1. The Amount of Investment SSBV to BPC and Credit of Bank to Debtors

\begin{tabular}{ccccc}
\hline \multirow{2}{*}{ No } & \multirow{2}{*}{ Years } & $\begin{array}{c}\text { Venture Capital } \\
\text { Investment }\left(\mathbf{X}_{\mathbf{1}}\right)\end{array}$ & $\begin{array}{c}\text { Credit From Bank } \\
\left(\mathbf{X}_{2}\right)\end{array}$ & \multirow{2}{*}{$\begin{array}{c}\text { The Number of } \\
\text { BPC SSBV (Y) }\end{array}$} \\
\cline { 1 - 3 } & & $(\mathbf{R p})$ & $\mathbf{( R p )}$ & \\
\hline 1 & 2005 & 18.926 .750 .000 & 56.416 .800 .000 &
\end{tabular}




\begin{tabular}{|c|c|c|c|c|}
\hline No & Years & $\begin{array}{l}\text { Venture Capital } \\
\text { Investment }\left(X_{1}\right)\end{array}$ & $\begin{array}{c}\text { Credit From Bank } \\
\left(\mathbf{X}_{2}\right)\end{array}$ & $\begin{array}{l}\text { The Number of } \\
\text { BPC SSBV (Y) }\end{array}$ \\
\hline 2 & 2006 & 21.784 .619 .500 & 77.187 .000 .000 & 15 \\
\hline 3 & 2007 & 22.916 .886 .000 & 86.114 .400 .000 & 68 \\
\hline 4 & 2008 & 33.551 .089 .443 & 110.375 .400 .000 & 29 \\
\hline 5 & 2009 & 30.303 .867 .895 & 123.997 .800 .000 & 17 \\
\hline 6 & 2010 & 29.797 .825 .010 & 195.008 .400 .000 & 31 \\
\hline 7 & 2011 & 28.573 .528 .800 & 105.982 .200 .000 & 294 \\
\hline 8 & 2012 & 49.188.000.000 & 76.804 .800 .000 & 464 \\
\hline 9 & 2013 & 57.211 .000 .000 & 173.902 .000 .000 & 537 \\
\hline 10 & 2014 & 53.661 .813 .337 & 283.063 .000 .000 & 300 \\
\hline \multicolumn{2}{|c|}{ Total } & 410.242 .348 .985 & 1.288 .851 .800 .000 & 1954 \\
\hline
\end{tabular}

Based on the data in Table 1, the results of regression "OLS equation model" within the period of 2005-2014 can be written as follows:

$\mathrm{Y}=-225,255+15,992 \mathrm{X}_{1}-1,160 \mathrm{X}_{2}$

$(-2,466) \quad(5,130) \quad(-1,875)$

Where the value of $\mathrm{R}$ Square $=0,806$; and the value of parameter coefficients are:

$\beta_{0}=-225,255 ; \beta_{1}=15,992 ;$ and $\beta_{2}=-1,160$.

\subsection{The interpretation of parameter values of "OLS equation model" can be explained} as follows:

a. $\quad$ R Square $=0.806$.

This means that the value of $\mathrm{R}$ Square is 0.806 indicating the value of variable $\mathrm{Y}=$ number of BPC influenced by independent variables X1 (VCC investment funds) and X2 (Bank loans) of $80.60 \%$ while $19.40 \%$ is influenced by other variables.

b. $\beta 0=-225.255$

This means that when the venture funds channeled to BPC are zero and bank funds channeled to the public are zero, the number of BPCs will be reduced by 225,255 units.

c. $\beta 1=+15,992$

This means that venture finance has a positive effect on increasing the number of BPCs. The implication is that if $\mathrm{X} 1$ (venture funds) increases by Rp1 billion, then the value of $\mathrm{Y}$ or the number of BPC will increase by 15,992 units assuming other variables do not change (Cateribus Varibus).

d. $\beta 2=-1.160$

This means that bank financing has a negative effect on increasing the amount of BPC which means that if the funds channeled by the bank increase, it will reduce the number of BPCs. If X2 (bank funds) increases by Rp1 billion, then the Y value (number of BPC units) will decrease by 1,160 units. 
e. Fcount $=14,544>$ Ftable 9.55 shows that variables $\mathrm{X} 1$ and $\mathrm{X} 2$ affect the development of the number of BPC with an error rate of around $1 \%$, while the level of trust is at the level of $99 \%$.

Finally, itt can be concluded that the results of the economic statistics analysis by using OLS equation model prove that the existence of venture capital companies in this case is the West Sumatra Venture Capital; abbriviated with SSBV has a significant influence to the development of small and medium industrial enterprises (SMIEs). The implication shows that the establishment of SMV in Solok City will have a positive and significant influence on the future development of SMIEs in the city of Solok

\subsection{Analysis and Discussion of Capital Need of SMIEs in Kota Solok:}

\section{a. Overview of SMIE's actors in Solok City:}

The age level of SMIEs actors varies between the ages of 25 years and 65 years. From the results of grouping the age of the respondents obtained the greatest variation is the age of $36-45$ years, namely 34 persons or 40.47 percent. The age of 46-55 years is 19 persons or 22.61 percent. And age of 56-65 years equal to 14 persons or 16.66 percent. Based on the age of the respondents it can be concluded that business actors in Solok City are dominated by productive age. This shows a huge potential for the development of SMIEs in Solok City in the future. In the productive age, business people are still open to receiving updates and breakthroughs to develop more creative and innovative businesses. In terms of the orientation of SMIEs in the city of Solok, data shows that of the 84 respondents of SMIEs actors taken by purposive random sampling, it was found that 76.19 percent or 64 people were industrial players. While 10.71 percent or 9 persons have a main business in agriculture, then 9.52 percent or 8 respondents have a main business as traders and then 2.38 percent or 2 respondents have the main business of a restaurant, the remaining 1.19 percent or 1 respondent has a business in other fields.

In terms of marketing, 63.10 percent or 53 respondents sold their products only within their own area, while 33.10 percent or 28 respondents sold their products in the West Sumatra region. However, there are also 2.38 percent or 2 respondents who distribute their products to all regions of Sumatra. Furthermore, from the results of data processing, it was also found that 71.43 percent or 60 respondents said that the average number of workers joining the SMIEs was 5 people, and then 23.81 percent or 33 respondents had a workforce of 10 people. In fact there are also 2.19 percent or 2 respondents who have 15 to 20 people who use their labor.

\section{b. SMIEs Capital Needs and the opportunity of VCC established in Solok City:}

Table 2 shows that the results of the questionnaire analysis indicate 65.48 percent of respondents or 55 persons who said that the source of their business capital come from their owned funds. Whereas 13.10 percent or 11 respondents obtained business capital from the banks, 2.38 percent or 2 people obtained business capital from cooperatives, even 19.05 percent or 16 respondents obtained loans from moneylenders with high interest. This moneylender is usually referred to as bank 46 , which is defined if the amount of loan equal to 4 then its return must be 6 , meaning that the interest rate paid for loans is 50 percent. It is quite expensive for SMIEs. Why do they accept of loans at high interest rates from rentenir? 
the simple reasons because of they are not capable to fulfill any requirements from bank. In average the start-up capital needed by SMIEs is normally equal to Rp 75.000.000. Table 2 shows that the amount of loan from bank totally is expected equal to Rp 6.150.000.000. But in realization the loans accepted is equal to $\mathrm{Rp} 3.020 .000 .000$., it indicate that there are $\mathrm{Rp}$ 3.130.000.000 as the difference between expectation and realization. These figures indicate that there will be a big opportunity of market for VCC. There are 51.19 percent or 43 people of respondents who stated the important of the alternative funding sources in the form of loans without compensation. Then 28.57 percent of respondents or 24 persons who want credit without compensation, then also accompanied by management assistance, including training and accomodation assistance. Respondents also revealed that the capital was needed when conducting business development. In addition, respondents also need assistance on how to develop business products and develop marketing networks so they can compete with other industry players.

Table 2. Capital Need of SMIEs in Solok City, 2015

\begin{tabular}{|c|c|c|c|c|c|}
\hline $\begin{array}{c}\text { The } \\
\text { number of } \\
\text { respondents }\end{array}$ & $\begin{array}{l}\text { Sources and Amount } \\
\text { of Capital needed }\end{array}$ & $\begin{array}{l}\text { Respondents: } \\
\text { Actors of } \\
\text { SMIEs }\end{array}$ & Percent & $\begin{array}{c}\text { The expected } \\
\text { loan } \\
\text { demanded }\end{array}$ & Lack of loans \\
\hline persons & $\mathbf{R p}$ & persons & $\%$ & $\mathbf{R p}$ & $\mathbf{R p}$ \\
\hline & A. Source of fund & & & & \\
\hline \multirow{9}{*}{84} & 1. Owned Fund & 55 & 65,48 & 4.125 .000 .000 & \\
\hline & 2. Bank & 11 & 13,10 & 825.000 .000 & 6.150 .000 .000 \\
\hline & 3. Rentenir & 16 & 19,05 & 1.200 .000 .000 & \\
\hline & Total & & & 6.150 .000 .000 & \\
\hline & B. Loans received & & & & \\
\hline & 1. $\leq 20$ million & 40 & 47,62 & 800.000 .000 & \\
\hline & $\begin{array}{l}20-50 \\
\text { million }\end{array}$ & 43 & 51,19 & 2.150 .000 .000 & 3.020 .000 .000 \\
\hline & $\begin{array}{ll}\text { 3. } & 50-70 \\
& \text { million }\end{array}$ & 1 & 1,19 & 70.000 .000 & \\
\hline & Total & & & 3.020 .000 .000 & 3.130 .000 .000 \\
\hline
\end{tabular}

\section{c. Prospective Analysis and Discussion of Venture Capital Companies In Solok City}

There are several obstacles for SMEs to get loans from banks. Especially for beginner companies, it is very difficult for them to meet the bank requirements because of they are not yet considered by bank as a bankable firm. Even for the firms which have several years experiences in the market are often facing as well difficulties when borrow money from bank. This kind of unfavorable environment pushes SMTIEs to search the alternative of financial support for their business development. In this case, the financial non-bank institution such as VCC can take the important role. Sovereign Capital, has actively assisted the company in devising new business concepts and introducing innovative management systems. Sovereign Capital, has actively assisted the company in devising new business concepts and introducing innovative management systems.[10].

From the primary data sourced from interviews and questionnaires, it shows that 70.24 percent or 59 people of the respondents said that they strongly need the financial assistance from VCC, and 25 percent or 21 respondents said that the establishment of VCC or SVC in 
Solok City is a necessary policy for the local government to take, while 3.57 percent or 3 respondents said they did not need it. Furthermore, 71.43 percent or 60 people said to start an industrial business, the most challenging transition is business capital to "get started". In this case they really need support from non-bank financial institution such as VCC. Then 13.10 percent or 11 people experienced problems due to lack of human resources, and 8.33 or 7 respondents said that they face the difficulty in relation with the source of raw materials. 59 respondents said that for the average production process the raw material came from the region itself and 22.62 percent or 19 respondents said that the source of the raw material used came from outside the region. In terms of the type of equipment used to process production, it turns out that 38.10 percent or 32 respondents use machine technology, and 34.52 percent or 29 people still use traditional tools and 14.29 percent or 3 people use other equipment. All of those will be better off if supporting by enough investment capital and easier to access them.

From point of view Human Development Index (HDI), see Table 3, if seen from the HDI of the Solok City in comparison with other regions in the West Sumatra Province, It is seen that Solok City's HDI is 77.44. In the year of 2017. It is a pretty good value because it is far greater than the figure of 50 and greater than 60, this is theoretically quite high. This means that in the context of the quality of Human Resources (HR) in Solok City, it can be said to be quite good and can support the development of SMIEs, of course, furthermore very beneficial for making Solok Venture Capital to become success. SMV in building cooperation with the elected BPC, the factor of human quality, his or her skill and knowledge are considered as the main condition required in order to select SMIEs to be Business Partner Company (BPC) or in Indonesian term is called as Perusahaan Pasangan Usaha (PPU).

According to the data questioners show that Solok City has in average of education of the workforce is 48.81 percent or 41 people are graduates of junior high school. Then 39.29 percent or 33 people graduated from senior high school. When viewed from the level of education of the workforce, it can be concluded that there is enough potential to be trained in conducting the production process and being educated to innovate in order to improve product quality. The development of innovation behavior in a certain society is key factor which can accelerate of SMIEs growth and make VCC working more efficiently and productively.

The data elaborated above basically illustrates that if SVC is established in the city of Solok, there is a great opportunity because it is supported by a fairly conducive SMIEs business environment. SMIEs will be freer to find sources of funding because they are not solely dependent on banks but can also access capital from non-Bank institutions, in this case is SVC.

Table 3. Human Development Index of Solok City Compared to Other Regencies / Municipalities in West Sumatra 2013-2017

\begin{tabular}{llcccccc}
\hline Regency / Municipality & \multicolumn{5}{c}{ Years } & & $\begin{array}{l}\text { Ranking } \\
(\mathbf{2 0 1 7})\end{array}$ \\
\hline & Regency & $\mathbf{2 0 1 3}$ & $\mathbf{2 0 1 4}$ & $\mathbf{2 0 1 5}$ & $\mathbf{2 0 1 6}$ & $\mathbf{2 0 1 7}$ & ( \\
1 & Kep. Mentawai & 56,33 & 56,73 & 57,41 & 58,27 & 59,25 & \\
2 & Pesisir Selatan & 67,31 & 67,75 & 68,07 & 68,39 & 68,74 & \\
3 & Solok & 66,15 & 66,44 & 67,12 & 67,67 & 67,86 & \\
4 & Sijunjung & 64,48 & 64,95 & 65,30 & 66,01 & 66,60 & \\
5 & Tanah Datar & 68,12 & 68,51 & 69,49 & 70,11 & 70,37 & \\
6 & Padang Pariaman & 67,15 & 67,56 & 68,04 & 68,44 & 68,90 & \\
7 & Agam & 68,73 & 69,32 & 69,84 & 70,36 & 71,10 &
\end{tabular}




\begin{tabular}{|c|c|c|c|c|c|c|c|}
\hline \multirow{2}{*}{\multicolumn{2}{|c|}{ Regency / Municipality }} & \multicolumn{5}{|c|}{ Years } & \multirow{2}{*}{$\begin{array}{l}\text { Ranking } \\
\text { (2017) }\end{array}$} \\
\hline & & 2013 & 2014 & 2015 & 2016 & 2017 & \\
\hline 8 & Lima Puluh Kota & 66,30 & 66,78 & 67,65 & 68,37 & 68,69 & \\
\hline 9 & Pasaman & 62,91 & 63,33 & 64,01 & 64,57 & 64,94 & \\
\hline 10 & Solok Selatan & 65,86 & 66,29 & 67,09 & 67,47 & 67,81 & \\
\hline 11 & Dharmasraya & 68,71 & 69,27 & 69,84 & 70,25 & 70,40 & \\
\hline 12 & $\begin{array}{l}\text { Pasaman Barat } \\
\text { Municipality }\end{array}$ & 63,92 & 64,56 & 65,26 & 66,03 & 66,83 & \\
\hline 13 & Padang & 79,23 & 79,83 & 80,36 & 81,06 & 81,58 & I \\
\hline 14 & Solok & 75,54 & 76,20 & 76,83 & 77,07 & 77,44 & IV \\
\hline 15 & Sawah Lunto & 69,07 & 69,61 & 69,87 & 70,67 & 71,13 & \\
\hline 16 & Padang Panjang & 74,54 & 75,05 & 75,98 & 75,50 & 77,01 & V \\
\hline 17 & Bukittinggi & 77,67 & 78,02 & 78,72 & 79,11 & 79,80 & II \\
\hline 18 & Payakumbuh & 76,34 & 76,49 & 77,42 & 77,56 & 77,91 & III \\
\hline 19 & Pariaman & 74,51 & 74,66 & 74,98 & 75,44 & 75,71 & \\
\hline \multicolumn{2}{|c|}{ West Sumatra } & $\begin{array}{l}68,9 \\
1\end{array}$ & 69,36 & 69,98 & $\mathbf{7 0 , 7 3}$ & 71,24 & \\
\hline
\end{tabular}

Notes :

HDI $<60=$ Low HDI; $60 \leq \mathrm{HDI}<70=$ Moderate HDI; $70 \leq \mathrm{HDI}<80=$ High HDI

HDI $\geq 80=$ Very high HDI

Source : BPS - Statistics of West Sumatra Province

\section{Conclussion}

a. The results of multiple regression prove that the existence of Solok Venture Capital (SVC) has a positive and significant influence in the effort to develop Small and Medium Industrial Enterprises (SMIEs) in Solok City. It is indicated by the value of parameter coeffisients $\left(\beta_{0}, \beta_{1}, \beta_{2}\right)$ for independent variables which are found significantly related to the dependent variable $(\mathrm{Y})$. With the results of the regression equation as follows:

\section{$\mathrm{Y}=-\mathbf{2 2 5 . 2 5 5}+15.992 \mathrm{X} 1-1,160 \times 2$}

$(-2,466) \quad(5,130) \quad(-1,875)$

Where:

$Y \quad=$ the number of BPC in the Province of West Sumatra, as a dependent variable;

$X_{1} \quad=$ the amount of investment of VCC (SSBV) to BPC in the Province of West Sumatra

$X_{2}=$ the amount of credit from bank to debtors in the Province of West Sumatra

$\beta_{0} \quad=$ intercept

$\beta_{1}, \beta_{2}, \quad=$ the value of coeffisients parameter of independent variables

b. Based on the survey results that SMIEs' main source of capital in starting-up their business comes from their own capital, it is according to answer of 65.48 percent of 84 total respondents (SMIEs), where the average initial capital in carrying out of their 
business is Rp. 75,000,000. The SMIEs borrow from bank consisted of 11 people with a total of IDR $825,000,000$. While those who take loans from moneylenders 19.05

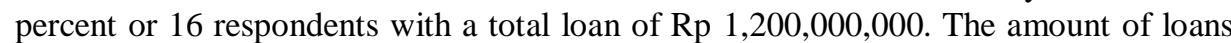
received by SMIEs players from the bank is based on the results of interviews with respondents, with varying loan rates, in all Rp. 3,020,000,000. While the expected amount of credit for all according the need of SMIEs (84 respondents) is Rp. $6,150,000,000$. This means that there is a shortage of funds Rp. 3,130,000,000. This shortage determine that there is a great opportunity for SVC to be established as a nonbank financial institution that plays a role as alternative financing sources for SMIEs in Solok City.

c. Judging from the results of the questionnaire, most of the respondents want the existence of non-bank financing institutions such as VCC in Solok City. Then if it is associated with the value of HDI, it turns out that Solok City has HDI greater than 50 or 77.44 in the year of 2017, a figure that is significant enough to say that the quality of human resources in Solok City is quite ready to adapt to the changes. This will certainly support the success of SMIEs and SVC.

\section{References}

[1] F. Tan, D. Sartika, and maidalena Maidalena, "SMALL MEDIUM TECHNOLOGICAL ENTERPRISES AND LOCAL ECONOMIC," Ponte Acad. J., vol. 74, no. 4, pp. 407-421, 2018.

[2] W. H. Y. Zhang, "New venture capability of the transformation from entrepreneurial orientation to new venture's performance Theory model and empirical study in China," 2012.

[3] H. Kachlami, "Social venture creation and the influence of commercial ventures," Soc. Enterp. J., vol. 12, no. 3, pp. 347-367, 2016.

[4] Y. Xu, "Entrepreneurial social capital, cognitive orientation and new venture innovation," Manag. Res. Rev., vol. 39, no. 5, pp. 498-520, 2016.

[5] Y. Yang, T. Chen, and lei zhang, "Corporate venture capital program autonomy, corporate investors ' attention and portfolio diversification," 2016.

[6] M. Chen and Y. Chang, "motivation and creativity The impacts of human capital in enhancing new venture' s performance Competence, motivation and creativity," 2013.

[7] J. Aizenman and J. Kendall, "The internationalization of venture capital," J. Econ. Stud., vol. 39, no. 5, pp. 488-511, 2012.

[8] S. M. Lee, T. Kim, and S. H. Jang, "Inter-organizational knowledge transfer through corporate venture capital investment," Manag. Decis., vol. 53, no. 7, pp. 1601-1618, 2015.

[9] D. Sartika, D. Asmanita, S. Fransisca, F. Tan, and D. Asniati, "Development Model for New Entrepreneur on Micro Small Medium Enterprises (Umkm) and Small-Medium Industrial Enterprises (Uikm) in Padang City,” PONTE Int. Sci. Res. J., vol. 74, no. 3, pp. 261-272, 2018.

[10] T. M. Nisar, "Venture capital support for creating portfolio company organizational capabilities," An Int. J., vol. Vol. 19 Is, pp. 2-5, 2012. 